\title{
資料「「国連持続可能な開発のための教育の10年」の 国際実施計画とその策定の背景
}

\author{
佐藤 真久・阿部 治 \\ 武蔵工業大学 ·立教大学 \\ (受理日 2007 年 11 月 17 日)
}

\section{DESD 国際実施計画 (IIS)の策定経緯}

2002 年にヨハネスブルクにおいて開催された 「持続可能な開発に関する世界首脳会議 (WSSD)」 では、「国連持続可能な開発のための教育の10年 (DESD)」が提案され、2002年 12 月の第 57 回国 連総会において、その実施 (DESD) が決議された。 この決議文書1）においては、DESDを2005年か ら 2014 年までの 10 年とすることが宣言されただ けでなく、以下の点が主文において強調されてい る。

・DESDの主導機関であるUNESCOに対し、「万 人のための教育 (EFA)」等の既存の教育推進 プロセスとの関係性を整理しつつ、国連諸機関 をはじめとする国際機関、各国政府、NGO等 と協議し、国家教育計画に盛り込む具体的対応 の指針となる国際実施計画案を作成するよう要 請する。

・各国政府に対し、UNESCOが作成する国際実 施計画案に基づき、DESDを実施するために必 要な具体的行動を国家教育計画に追記するよう 呼びかける。

この国連決議に基づき、2003年 7 月にはDESD 国際実施計画草案 ${ }^{2)}$ が発表された。この草案は、 第一章 :「持続可能な開発のための教育 (ESD)」、 第二章：「DESDに対するパートナーシップ・ア プローチ」、第三章 :「DESDの開始」から構成さ れている。本草案では、DESDにおける実施目的、 対象領域、主要テーマ ${ }^{3)}$ の明記だけでなく、 EFA、「国連識字の10年 (UNLD) 」、「ミレニア ム開発目標 $(\mathrm{MDGs}) 」$ とった国際的教育イニ シアティブとの連関の必要性や、パートナーシッ プ構築の重要性が指摘されており、2003年 7 月
から 2005 年 12 月までをDESD準備段階とする事 業予定が記載されている。とりわけ、本草案では、 DESDで取り扱うべき主要テーマとその相互関係 性、各実施主体のオーナーシップの醹成とコミッ トメントを促すためのパートナーシップ・アプ ローチの主要原則が詳しく明記されており、ま た、地域レベルのイニシアティブに対する支援の 重要性とその支援構造の改善が強調されている。

2003年 9 月にはUNESCO と国連関係機関との 協議が始まり、国際実施計画策定のためのフレー ムワークが広範囲に配布され、2000件を超える 意見が寄せられた。その後、当該分野において 指導的な立場にある学者や専門家による検討を経 て、2004年 7 月に開催されたDESDハイレベル パネル（UNESCO 事務局長への助言）に本草案 は提出されている。草案は、第59回国連総会 (2004 年10月、ニューヨーク）で報告されるとともに、 その後、加筆・修正のプロセスを経て、2005年 1 月にはDESD 国際実施計画最終案 ${ }^{4)}$ が作成さ れ、第171回UNESCO 執行委員会 (2005年 4 月、 パリ）へ報告がなされた。

この国際実施計画最終案は、第一章 :「持続可 能な開発のための教育 $(\mathrm{ESD})$ 」第二章 :「ステー クホルダーと戦略」、第三章：「実施および評価」、 第四章：「10年をプログラムする」、付録、から 構成されており、価值観の醸成、ESDが有する 特徵、視点（社会・文化的、環境的、経済的各 側面)、学習の場についての言及がなされている。 また、ステークホルダーの役割や機能、戦略など が記載されているとともに、10年間を一貫した プログラムとして機能させていく際の、活動の柱 の設定や人的・物的な資源分配、時系列による活 動計画が記載されている。

\section{問い合わせ先 干224-0015 神奈川県横浜市都筑区牛久保西3-3-1 武蔵工業大学環境情報学部 佐藤真久研究室} Tel. 045-910-2564, E-mail: m-sato@yc.musashi-tech.ac.jp 
この国際実施計画最終案によって、15の戦略 テーマ (Strategic Theme) が三つの視点（社会・ 文化的側面、環境的側面、経済的側面）によって 整理 ${ }^{5)}$ されたほか、倫理・価值観が強調される とともに、ESDが有する特徵 ${ }^{6)}$ が記述されたこ とは大変意義深い。また、学習の場を学校教育だ けでなく、高等教育機関や、教員訓練機関、政策 決定機関、などを対象とするほか、ノンフォーマ ル教育、インフォーマル教育、コミュニティ、職 場を学習の場として位置づけている点も意義深い といえよう。その後、DESD国際実施計画最終案 は改訂され、第 172 回UNESCO 執行委員会 (2005 年 8 月、パリ）において、DESD 国際実施計画 (IIS) 7 ) が採択された。

\section{DESD 国際実施計画 (IIS) の概要}

国際実施計画（IIS）は、第一章 :「国際実施計 画の目的」、第二章:「持続可能な開発のための 教育の 10 年」、第三章 :「DESDにおける責任 パートナーシップと連携によるアプローチ」、第 四章 :「鍵となる道標(Key Milestone)」第五章 : $\lceil\mathrm{DESD}$ の実施」、および付属文書 I：「持続可能な 開発のための教育の背景」から構成されており、 要点は以下のとおりである。

-DESDの目標 : 持続可能な開発の原則、価值観、 実践を、教育と学習のあらゆる側面に組み込む こと

・DESDのビジョン：誰にとっても教育から恩恵 を受ける機会があり、そして持続可能な未来の 構築と現実的な社会転換のために必要な価值観 や行動、ライフスタイルを学習する機会がある 世界

・DESDの目的：(1) ESDのステークホルダー間 のネットワーク、連携、交流、相互作用を促進 する；(2) ESDにおける教授と学習の質の改 善を促進する；(3）ESDの取り組みを通して、 「ミレニアム開発目標」に向けて前進し、これ を達成できるよう各国を支援する；(4) 教育改 革の取り組みにESDを組み込むための新たな 機会を各国に提供する

-4つの主目的：(1) 質の高い基礎教育へのアク
セスの向上 ; (2) 既存の教育プログラムの新た な方向づけ；(3) 持続可能性に関する人々の認 識と理解の向上 ; (4) 訓練の提供

- 4 つの領域：(1) 社会的領域（雇用、人権、男 女間の公平、平和、人間の安全保障など）(2) 環境的領域（水問題や廃棄物問題など）; (3) 経済的領域（貧困削減、企業の責任と説明能 力など）；(4）横断的領域（HIV/AIDS、移民、 気候変動、都市化)

・7つの戦略：(1) ビジョン構築と提言活動;

（2）協議と主体者意識；（3）パートナーシップ とネットワーク；(4) 能力開発と訓練 ; (5) 研 究開発とイノベーション；(6) 情報通信技術の 活用；(7) モニタリングと評価

第一章 :「国際実施計画の目的」においては、 今日の国際実施計画に至る策定プロセスが述べら れるとともに、今後の DESD推進のためには、各 ステークホルダー間のパートナーシップと、主体 者意識（オーナーシップ）の醉成が不可欠である ことを強調している。

第二章 :「持続可能な開発のための教育の 10 年」 においては、DESDの目標とともに、ビジョン、 目的が書かれている (上述)。さらに、「現実的 な社会転換 (Positive Societal Transformation)」 という言葉を使用し、行動や態度、価值観として 表れるような教育の実施が重要であることを強調 している。また、DESDの主目的は、アジェンダ 21 第 36 章から引用されており、本文書が今日ま での国際的議論を反映していることが窥える。

第三章：「DESDにおける責任ーパートナー シップと提携によるアプローチ」においては、実 施主体として様々なステークホルダーの機能と役 割について述べられているだけではなく、DESD の主導機関としてUNESCOの果たすべき機能と 役割についても言及がなされており、国際実施計 画最終案に比べてょり詳細な記述がなされている 点が特徴であろう。

第四章：「鍵となる道標」においては、加盟各 国間で共通する道標が挙げられており、加盟国間 でのDESDに関する進渉状況の確認や比較を可能 なものにしている。 
第五章：「DESDの実施」においては、DESD の実施に向けた 7 つの戦略（上述）の提示がなさ れており、その戦略を遂行していく上でのインフ ラの構築と資源投入についての指摘が記述されて いる。インフラの要素としては、人材、財源、物 的資源だけではなく、リーダーシップ、ガバナン スの構造、運営管理の支援、作業手順、アカウン タビリティ、評価・モニタリング・報告、ビジョ ン構築、スタッフの雇用と維持、などの広範囲に わたる配慮が重要視されている。また、物理的な インフラだけではない、実施アプローチや意思決 定にも配慮したものになっている。資源に関して は、とりわけ、財政面の不足が指摘されており、 政府・ドナー機関に対し、既存の資金の再配分の 検討と、資金源の確保を要請している。

国際実施計画の付属文書 I：「持続可能な開発 のための教育の背景」には、ESD 概念の由来に 関する文書が記載されている。付属文書による と、ESDには 2 つの流れがあり、それは「持続 可能な開発と教育」の流れと、「基礎教育の質の 向上とアクセスの改善」の流れであるとし、双方 の歴史的な背景が記載されている。国際実施計画 は、2003年に発表された国際実施計画草案に比 べ、持続可能性の諸問題」に基づく環境と開発 の視点から、教育の価值・質・プロセスにその重 点がシフトしてきていることが窺える。

「持続可能性にむけた諸問題」についての指摘 を見てみると、国際実施計画最終案 (2005年 1 月）の段階では、社会・文化的側面、環境的側面、 経済的側面の 3 つの視点 (Perspectives) におい て15の戦略テーマに関する記述が詳細に書かれ ているだけでなく、各ステークホルダーが果たす べき役割と機能・作業項目についても詳細に記述 している。しかしながら、その後の国際実施計画 （2005年10月）になると、「持続可能性に関する 諸問題」についての記述は、4つの領域 (Sphere) によって整理はされているものの、大幅にその記 述が削除されている。この記述内容の大幅な削除 によって、DESDにおいて配慮すべき諸問題につ いての具体性を欠いたものになったことは否めな い。しかしながらその一方で、アジェンダ 21 第
36 章の教育目的を採用し、また、ビジョンの記 述、価値観の重要性の強調、質の高い基礎教育の 重視、国際的教育イニシアティブとの連関の重要 性の指摘、主導機関としてUNESCOの役割の明 確化について言及をしている点は、評価に值する といえよう。

また、国際実施計画の付属文書には、ESD の主な特徵の一つとして、「ESDは進展して いく持続可能性という概念に対応する（ESD accommodates the evolving nature of the concept of sustainability)」との指摘がある。国 際実施計画草案から、国際実施計画最終案、国際 実施計画へと ESD 概念と手法が構築されていく なかで、量的・質的に記述内容が大きく変化を遂 げてきていることは、まさに概念そのものが進展 している結果であるということができよう。

日本においては、国際実施計画案における国際 教育計画の策定要請を受けて、2006年 2 月 3 日 に「わが国における持続可能な開発のための教育 の 10 年実施計画案」が公開され、同年 3 月 30 日 に実施計画が発行された。今後、様々なステーク ホルダーとの対話のもとで作業がすすむことが期 待されているとともに、地域実践を通して、進 展しつつある $\mathrm{ESD}$ 概念そのものの議論と、持続 可能性にむけた知の獲得・共有が必要とされてい る。

本稿では、「持続可能な開発のための教育」に 対する基本的な理解として不可欠と思われる、 ESDの由来について書かれた付属文書 I：「持続 可能な開発のための教育の背景」を、以下に抄訳 で紹介する。DESD国際実施計画（IIS）そのも のについては機会を改めて紹介することとする。

\section{3 「付属文書 I : 持続可能な開発のための教育 の背景」の日本語訳}

本付属文書では、ESDの進展やその由来につ いてなど、ESDの背景を概説している。本稿では、 $\mathrm{ESD}$ の由来、「質の高い教育」と ESD との重要な 結びつきについて述べ、ESDの 4 つの目的を概 説し、ESDの主な特徴を列挙する。 


\section{A. 持続可能な開発のための教育の由来}

1948年の「世界人権宣言」では、「すべて人は、 教育を受ける権利を有する」とされている。こ の教育の権利は、1989年の「子どもの権利条約 $(\mathrm{CRC}) 」$ でさらに強化され、初等教育を義務的な ものとし、万人に対して無償のものとすると宣言 した。さらにCRCでは、子どもが、人種、性別、 障害、経済状況によって、教育も含めいかなる権 利からも除外されてはならないとしている。

1990 年のジョムティエンにおける「万人のた めの教育世界宣言」では、「基礎教育はすべての 子ども、青年、成人に提供されなければならない。 このために、質の高い基礎教育の提供を拡大し、 格差を是正するために首尾一貫した方策を取らな ければならない」（万人のための教育世界宣言、 1990 年、第 2 条ビジョン構築）と宣言している。 同宣言ではさらに、男女格差とその対処法につい ても言及している。「最も差し迫った優先事項は、 少女と女性が教育へアクセスできるよう徹底し、 その教育の質を向上させるということ、さらに、 少女と女性の教育への積極的な参加を阻害するあ らゆる障害を排除することである。教育における 性差に関するあらゆる固定観念を取り除かなけれ ばならない」（万人のための教育世界宣言、1990 年、第 3 条アクセスの普遍化と公平性の推進)。

さらに国際開発目標（IDT）でも、「質の高い 教育」について進展が見られる。「ダカール行動 枠組み」では、6つの重要な教育目標を揭げてい る。その第 6 目標は、「教育の質のあらゆる側面 を向上させ、特に識字能力、計数能力、不可欠 なライフスキルにおいて、人々が認知でき、計測 可能な学習の成果が達成されるようにする」とし ている。「ミレニアム開発目標（MDGs）」もまた 教育に言及をしている。MDGsの第 2 目標は「普 遍的初等教育の達成」である。これに対応する IDTでは「2015年までに、すべての子どもが男 女の区別なく初等教育の全課程を修了できるよう にする」としている。MDGsの第 3 目標は「男女 平等及び女性の地位強化の推進」である。これ に対応するIDTでは「可能な限り2005年までに 初等・中等教育における男女格差を解消し、お
そくとも2015年までにすべての教育レベルにお ける男女格差を解消する」としている（国連ミ レニアム・プロジェクト、2005年)。さらに、国 連総会は 2003 年から 2012 年を「国連識字の 10 年 (UNLD)」とすると宣言した。国連がその歴史の 中で、「万人のための教育」の重要性を繰り返し 呼びかけてきたことは明白である。一方、持続可 能な開発は、国連の歴史の中で、環境問題への取 り組みに端を発している。持続可能な開発のため に現在も行われている取り組みの大半は、その発 端を数十年前にさかのぼることができる。持続可 能な開発へ向かう歴史の中で、1972年にストッ クホルムで開催され、歴史に節目を刻んだ「国 連人間環境会議」など、多くの画期的な出来事 があった。その結果、国連環境計画 (UNEP) な ど、環境保護のための機関が多数設立された。ま た、環境の悪化が広範囲に広がり、各国ごとのア プローチや解決策よりも国際的な配慮と協働が必 要だと各国は認識するようになった。

このような環境問題に本質的に備わっている社 会的および経済的問題へもある程度は配慮が向け られたものの、大きな注目を集めたのは、無制限 な開発が絶えず進められることによる生態学的な 影響であった。「国連人間環境会議」以降の 10 年 間で世界が気づいたことは、多数の人々を苦しめ ている貧困などの開発問題から離れて環境問題を 論じても、環境や人間のためにはならないという ことだ。こうして1980年代の半ばには、社会と 環境の双方のニーズに対処するために、国連はよ り大きな戦略のための研究に着手した。1987年 にブルントラント委員会が発表した報告書、『我 ら共有の未来』によって、政府のあらゆるレベル における将来の開発政策の重要な枠組み・構成概 念を包括するものとして、「持続可能な開発」は 支持された。このように、持続可能な開発のため の教育（ESD）は、質の高い教育とアクセス、持 続可能な開発という、2つの異なる国連の関心事 項の歴史の中に端を発している。

1987 年に初めて持続可能な開発という概念が 支持された時から、持続可能な開発を支える教育 の概念について国連総会で検討が行われてきた。 
1987 年から 1992 年にかけて、さまざまな委員会 で討議や交渉が行われ、40章からなる「アジェ ンダ $21 」 か ゙$ 作成されることを通して、持続可能 な開発という概念が成熟してきた。教育と持続 可能性についての考察が初めて記載されたのが、 「アジェンダ $21 」 の$ 第 36 章「教育、意識啓発及び 訓練の推進」である。さらに、「アジェンダ21」 の全 40 章の各章および「地球サミット」での交 渉から成立した諸協約においても、持続可能な開 発を可能にし、実施するための戦略として教育が 盛り込まれている。これに加えて、持続可能性に 関する問題の更なる掘り下げ、より緻密に検討を 行った1990年代の主要な 9つの国連会議8)すべ てが、最も幅広い意味での教育を、これらの会議 の行動計画の実施に不可欠なものと認めたのであ る。

2002 年のヨハネスブルグにおける「持続可能 な開発に関する世界首脳会議 (WSSD)」では、 地方から世界レベルまで、すべてのレベルでの持 続可能な開発に向けたコミットメントを深めるこ とが促された。WSSDは「国連持続可能な開発の ための教育の 10 年 (DESD)」を提案し、教育と 学習が持続可能な開発に向けたアプローチの中心 にあることを示した。

教育と持続可能な開発の双方を支援する国連の 長い歴史の中で、DESD は次なるステップである。 DESDは、教育に対する目下の関心と持続可能 な開発に関する現在の重要なテーマとを結びつけ る。持続可能な開発のための教育は大きな影響力 を持つ概念であり、世界中の人々の関心を湧き立 たせ、より持続可能な未来を形づくる手段として 教育が活用されるようになる可能性がある。

最近発表された「ミレニアム生態系アセスメン 卜」の報告書には、これまで行われた取り組みは、 どう見ても不十分であると記述されている。貧困 と飢餓の削減、人々の健康の向上、そして環境保 護などの目標に取り組むには、より多くの情報に 基づいた、より戦略的な方策が必要である。現在 では、「質の高い教育」には、文化的に適切なさ まざまな形態で実施可能であるという、きわめて 重要な特質が備わっている。

\section{B. 質の高い教育}

「質とは、社会的および経済的変化を大きく遂 げている社会を有する世界に対して常に適応して いかなくてはならない、という動的な概念となっ た。未来志向の考え方や予想の推進が、重要性を 増している。質についての古い概念はもはや十分 ではない.......状況の違いがあるにもかかわらず、 「質の高い教育」の追求には共通する多くの要素 がある。「質の高い教育」は男女ともすべての人々 に提供されなければならない。彼らは皆、コミュ ニティのメンバーそして世界市民として、この教 育に参加する」(教育の質に関する閣僚円卓会議、 UNESCO、2003、p.1)

EFA とMDGsは、その目的と国際開発目標 （IDT）に「質の高い教育」という概念を盛り込 んだ。質を無視した教育を提供しても、この目標 に合致しない。教育の質よりも教育へのアクセス を優先すべきだという、誤った通説がある。教育 の質と教育へのアクセスの提供は同時に実行でき る。

「質の高い教育」とは何かということについて は、幅広い議論が続いている。「質の高い教育」は、 ・あらゆる教育の取り組みに対し、権利に基づい たアプローチを支援する。教育は人権の 1 つで あり、それゆえに、「質の高い教育」はあらゆ る人権を支える。

・知ることを学ぶ、成すことを学ぶ、他者と共に 生きることを学ぶ、人間として生きることを学 ぶという、万人のための教育の 4 本の柱に基づ $<$ (Delors, et al., 1996)。

・学習者を個人、家族の一員、コミュニティのメ ンバー、世界市民として認識し、各人が、上記 4つの能力を身につけるよう教育する。

・持続可能な世界という理想を支持し、人々に伝 える。この世界は、公正で、平等で、平和で、 各自が世代間の公正に寄与すべく環境を大切に する。

- 特定の場所における社会的、経済的、環境的状 況を考慮に入れて、これらの特有の状況を反映 させたカリキュラムやプログラムを策定する。 「質の高い教育」は、地方に根ざし、文化的に 
も適切なものである。

・古来からの知識（その土地固有の知識や伝統的 な知識など）に基づき、現代の知識にも適して おり、未来にむけて各人が備える。

・知識、ライフスキル、洞察力、態度、価值観を 育む。

・現在の社会をより持続可能な社会に変えるため の手段を提供する。

・計測可能である。

\section{C. 持続可能な開発のための教育}

教育は持続可能性の中核を成すものである。実 際、教育と持続可能性はしっかりと結びついてい るものの、私たちが知っている教育と持続可能性 のための教育の違いは、多くの人々にとって不可 解である。ESDには本質的に、地方に根ざして 文化的にも適切なプログラムを実施するという考 えが内在している。ESDも含め、すべての持続 可能な開発に関するプログラムでは、環境、社 会（文化も含む）、経済という持続可能性の 3 つ の領域を考慮しなければならない。ESDではこ れらの 3 領域において地方ごとの状況に対処する ので、その形態は世界各地で異なるものとなるで あろう。世代間の公平、男女間の公平、社会的寛 容、貧困削減、環境の保護と回復、天然資源の保 全、公正で平和な社会など、持続可能性の基礎と なる理念と原則を、ESD は土台としている。「リ オ宣言」は持続可能性の原則を以下のように示し ている。

・人類は、自然と調和しつつ健康で生産的な生活 をおくる資格を有する。

・開発の権利は、現在世代および将来世代の開発 と環境上の必要性を公平に充たすことができる ように行使されなければならない

・世界のさまざまな場所で、貧困を撲滅し、生活 水準の格差を是正させることが、持続可能な開 発に不可欠である（Keating, 1993）

持続可能性に取り組むために、ESDの創出や 既存の教育の新たな方向づけを行う上で、その土 台となる知識、原則、技能、価值観とは何かを、 政府、コミュニティ、学校制度が判断する際に、 上記の原則が役立つであろう。

\section{D. 持続可能な開発のための教育の 4 つの目的}

「アジェンダ21」第 36 章は、持続可能な未来を 支えるための教育の 4 つの目的を明確にした。

\section{「質の高い基礎教育」へのアクセスの向上}

ESDの最優先課題は、基礎教育へのアクセス およびその質を改善することである。基礎教育 の内容と対象年数は世界各地で大きく異なってい る。例えば、ある国々では初等学校が基礎教育の 場と考えられているが、 8 年〜 12 年の基礎教育 を義務づけている国々もある。多くの人々、特に 少女と非識字の成人にとっては、基礎教育へのア クセスは今なお困難である。初等教育の就学年齢 にもかかわらず就学していない子どもは 1 億人を 超え、非識字の成人はおよそ8 億人である（『2004 年 EFAグローバル・モニタリング報告』)。多く の国々では、基礎教育の現状レベルが低すぎて、 持続可能な未来のための国家計画を推進すること ができない状態にある。「質の高い基礎教育」と いうこの ESDの目的こそが、EFAと MDGs と最 も密接に結びついているところである。

しかしながら、この ESDの必要性は、教育達 成度が低い国々に限られるわけではない。各国 が、万人への「質の高い教育」の提供に関連する 独自の諸問題を抱えている。識字率が高く、より 高度な教育が提供されている国々でさえ、非常に 多くの子ども、青年、成人が、現在でも十分な 教育を受けていないし、教育機会が制限されてい る。例えば、中途退学率が高い事例や、生涯学習 へのアクセスが限られていることもありうる。

基礎教育へのアクセスに関連する諸問題は、開 発途上国の問題だと捉えられることが多いが、先 進国にも共通する重要な問題がある。先進国に とってアクセスは必ずしも問題として大きいわけ ではないが、生徒が学校に継続して在籍するかど うかが、今なお大問題なのである。自分たちが生 活し競争し合う 21 世紀に向け、自らの準備が整 う前に、非常に多くの生徒が退学をしてしまう。 先進国では、中・高等学校の中途退学者には、縮 小する労働市場へのアクセスが非常に限られてし まう。成功した生徒を人種、民族、好みの学習ス タイルごとに追跡調査をした結果、先進国の大都 
市に暮らしているさまざまな背景を持つ若年層に 対して、教育を提供する上で、学校制度に弱点が あることが明らかになった。

残念なことに、大半の国々で現在教えられてい るような、単なる基礎識字の向上では、持続可能 な社会を推進させることはできないであろう。持 続可能性の目標に向かって前進することを望むコ ミュニティや国家は、市民参加とコミュニティの 意思決定を促進し支援するための知識、技能、価 值観、洞察力に的をしぼらければならない。これ を達成するには、持続可能性に取り組むために基 礎教育の新たな方向づけを行い、そして、批判 的思考の技能、データと情報をまとめ解釈する技 能、問題を明らかにする技能も扱うよう、基礎教 育を拡大しなければならない。

基礎教育はさらに、コミュニティが直面してい る問題を分析する能力も扱い、天然資源を損なわ ず、近隣の人々の社会的公平と公正を侵害しない ライフスタイルを各自が選択できるようにしなけ ればならない。

\section{既存の教育プログラムの新たな方向づけ}

現在教えられているような基礎教育では、より 持続可能な社会は構築されないであろう。自分た ちのライフスタイルを支えるために大量の資源と エネルギーを消費し、最大のエコロジカル・フッ トプリント9）を残しているのは、教育が提供さ れている国々である、という難問は依然として解 決されないままである。教育の量を増やすだけで は、より持続可能な未来は構築されないであろ う。問題は、教育の内容と妥当性なのである。幼 稚園から大学まで、教育について疑問を持ち、再 考し、修正して、環境、社会、経済の各領域に おける持続可能性に関連するより多くの原則、知 識、技能、洞察力、価值観を教育に取り入れるこ とが、私たちの現在そして未来の社会にとって必 要である。これは、社会全体が参加して包括的か つ学際的に行うべきであるが、各国は地方に根ざ して文化的にも適切な方法でこれを実施しなけれ ばならない。

\section{持続可能性についての人々の理解と認識の向上}

より持続可能な社会に向かって前進するには、
人々が持続可能性の目標を認識し、これらの目標 に資するための知識と技能を身に着けることが要 求されている。知識のある市民は、いくつもの 方法で、社会がより持続可能になるよう支援でき る。まず、市民は毎日のふるまいを通して、資 源管理と市民の行動に関する政策を支援する。第 2 に、持続可能な開発に関する施策や優れた法律 を導入し支持している政治家を、市民は支援でき る。第 3 に、市民は知識ある消費者になることが できる。市民はライフサイクルの影響が低い財を 購入し、自らの購買力で企業の社会的・環境的責 任や持続可能な事業を支援できる。十分な情報を 持つ市民は、コミュニティと政府が持続可能性の ための施策を定めてょり持続可能な社会へと前進 するのを手助けできる。

知識ある市民の育成には、あらゆる年代の人々 に伝達される首尾一貫した現実的なメッセージと 一致した取り組みが必要であろう。メディアに よる大規模なキャンペーンを行えば、社会のかな りの部分の人々に呼びかけることができる。さら に、行動変革のためのより簡単ないくつかの手法 を普及させるために、ソーシャル・マーケティン グも検討すべきである。コミュニティや国家が直 面している、より複雑な持続可能性に関する諸問 題について考えることができるように市民の能力 を育むためには、批判的思考と合理的な意思決定 に欠かせない技能に焦点を当てた、より包括的な 教育の手法が必要である。

\section{訓練の提供}

商業、工業、高等教育、政府、NGO、コミュ ニティ団体などのあらゆる部門は、環境マネジメ ントや公平性ある政策などの持続可能性に関する 諸問題に関して、リーダーを訓練しなければなら ない。また、これらの部門は、リーダーのもと で働く労働者が持続可能な行動を取れるような訓 練を奨励しなければならない。あらゆる部門の労 働者が持続可能な形態で働くために必要な知識と 技能を身につけられるように、特別の訓練プログ ラムを開発することは、ESDの必須要素である。 最近、特に製造業界の大企業は、エネルギー、水、 廃裹物管理に関する諸問題に対処するための訓練 
を導入することで、莫大な金銭的利益を上げてい る。その他の環境、社会、人的資源関連の諸問題 に取り組んでも、その努力は報われると立証され ている。実際に、いくつもの一流のビジネス・ スクールでは、持続可能な開発を必須科目として カリキュラムに導入している。しかしながら、世 界の産業界の $99.7 \%$ 占めるのは中小企業で、世 界の労働者のおよそ75\%を雇用している。今後、 中小企業も巻き込むための新たなアプローチの開 発が求められる。

以上の 4 つの目的が盛り込まれた ESDプログ ラムを創出するためには、教育界のあらゆる部門 が協力して共に取り組まねばならないであろう。 また、フォーマル教育のパートナー（初等、中等、 中等以降の高等教育など）は、従来のノンフォー マル教育部門のパートナー（例えば、ネイチャー センター、NGO、公衆衛生の指導者、農業普及 員など）および新しい夕イプのインフォーマル教 育部門のパートナー（つまり、テレビ、ラジオ、 新聞や雑誌などの出版業界を含むメディア）と 密接に協力して取り組まねばならないであろう。 ESDは生涯を通じたプロセスなので、これらの 各部門は、様々な年代の市民生活に影響を及ぼす ことになる。

\section{E. 持続可能な開発のための教育の主な特徵}

$\mathrm{ESD}$ に普遍的なモデルは存在しない。持続可 能性の原則とそれを支える概念については、全体 的な合意がなされているものの、地方の状況、優 先事項、アプローチによって、微妙な違いはあ るであろう。各国は、自らの持続可能性を定義 し、教育における優先事項と行動を定めなければ ならない。それゆえに、地方ごとの目標、重要事 項、プロセスは、文化的に適切な方法で、その地 域ごとの環境、社会、経済状況に合致するように 定めなければならない。ESD は、先進国と開発 途上国の双方に適切で重要なものである。また、 $\mathrm{ESD}$ の主な特徴は、文化的に適切なさまざまな 形態で実施可能である。

持続可能な開発のための教育は、

- 持続可能な開発の基礎となる原則と価值観に基 つくく
- 環境、社会、経済という持続可能性の3つの領 域すべてが健全な状態であるように取り組みを 行う

・生涯学習を推進する

・地方に根ざし、文化的にも適切である

・地方のニーズ、認識、状況に基づくが、地方の ニーズを充たせば国際レベルでもその影響が及 ぶことが多いということも認識する

・フォーマル、ノンフォーマル、インフォーマル 教育に取り組む

・進展していく持続可能性という概念の本質に対 応していく

- 状況、世界的な問題、地方ごとの優先事項を考 慮に入れて、教育の内容を検討する

・コミュニティに基づいた意思決定、社会的寛 容、環境的責任、変化に適応できる労働力、生 活の質という課題に対処できる市民の能力を育 成する

・学際的である。ESDは1つの学問分野に収ま るものではなく、あらゆる学問分野がESDに 貢献できる

・参加型学習および高次元の思考技能を育むさま ざまな教育方法を活用する。

このようなESDの主な特徵を実施可能にする 方法は無数にある。その結果、ESD プログラムは、 各地方にある独自の環境、社会、経済の状況が反 映されるものとなる。さらに、労働力、社会的寛 容、環境的責任、コミュニティに基づいた意思決 定、生活の質の向上と改善を通して、ESDは市 民の能力を育成する。フォーマル、ノンフォーマ ル、インフォーマル教育を連携させて、市民能力 の向上を行わねばならない。

\section{4 おわりに}

現在、アジア太平洋地域においては、国際実施 計画に基づき、国別のDESDのモニタリング ・ 評価活動が開始されている。ESD活動の進渉を 国レベルで把握するのは多くの困難が予想される が、その一方で、帰属する地域社会において、従 来の教育実践を ESDの視点から意味づける活動 や、ESDの特徵に配慮した新たな活動も見受け 
られる。国際実施計画がその策定プロセスを通し て大きく変化してきた背景を踏まえると、関わる 人々が「持続可能性」について自ら問いつづけ、 共有し、思考錯誤しながら教育実践をし、その意 味づけを継続的に実施・構築していくことが重要 であるといえる。

\section{注}

1) UNGA A/RES/57/254

2 ) UNESCO. 2003. United Nations Decade of Education for Sustainable Development 2005-2014, Framework for a Draft International Implementation Scheme, July 2003, UNESCO, Paris.

3 ）貧困の克服, ジェンダーの平等, 健康の増進, 環境保護 - 保全, 農村の変革, 人権, 異文化間 の理解と平和, 持続可能な生産と消費, 文化的 多様性, 情報通信技術

4 ) UNESCO. 2005. United Nations Decade of Education for Sustainable Development 2005-2014, Draft International Implementation Scheme, January 2005, UNESCO, Paris.

5 ）（1）社会 - 文化的側面 - 人権, 平和 - 安全保 障, 男女間の公平性, 文化の多様性と異文化理 解, 健康, HIV/AIDS, ガバナンス ; (2) 環境
的側面一天然資源, 気候変動, 農村開発, 持続 可能な都市化, 災害防止と軽減 ; (3) 経済的側 面一貧困削減, 企業責任と説明能力, 市場経済 6 ）学際性・統合性, 価值による牽引, 批判的思 考と問題解決, 多様な方法, 参加型意思決定, 応用性, 社会的適合性

7 ) UNESCO. 2005. United Nations Decade of Education for Sustainable Development (2005-2014), International Implementation Scheme, October 2005, UNESCO, Paris.

$8 ）$ これら 9 つの会議とは, 1990年の「子どもの ための世界サミット」,「万人のための教育世界 会議」, 1994 年の「国連人口開発会議」,「小島 嶼開発途上国の持続可能な開発のための国連グ ローバル会議」, 1995年の「世界社会開発サミッ ト」, 「第 4 回世界女性会議」, 1996年の「第 2 回 国連人間居住会議」,「世界食糧サミット」, 2000 年の「世界教育フォーラム」(UNESCO 2002)

9 )「人間生活により消費される資源量を分析 · 評価する手法のひとつ。人間 1 人が持続可能な 生活を送るのに必要な生産可能な土地面積（水 産資源の利用を含めて計算する場合は陸水面積 となる）として表示」（引用先； EICネット： http://www.eic.or.jp/ecoterm/) 